\title{
Population dynamics of early shoot borer, Chilo infuscatellus Snellen on sugarcane as influenced by weather conditions
}

\author{
Kanwar Kumar* \\ Department of Entomology, CCS Haryana Agricultural University, Hisar-125004 \\ (Haryana), India \\ Maha Singh Jaglan \\ CCS Haryana Agricultural University, Regional Research Station, Karnal-132001 \\ (Haryana), India \\ Tarun Verma \\ Department of Entomology, CCS Haryana Agricultural University, Hisar-125004 \\ (Haryana), India \\ *Corresponding author. E-mail: kanwarkumar1117@gmail.com
}

\begin{abstract}
A field experiment on population dynamics of early shoot borer, Chilo infuscatellus Snellen on sugarcane was carried out during 2016-17 crop season at the research farm of CCS Haryana Agricultural University, Regional Research Station, Karnal. Studies on population dynamics revealed thathighest incidence (3.81 per cent in $\mathrm{CoH} 160,4.60$ per cent in $\mathrm{CoH} 119$ and 3.12 per cent in CoS 767) of C. infuscatellus was recorded during $24^{\text {th }}$ SMW. Correlation of $C$. infuscatellus population with various environmental factors revealed that there was a significant positive correlation with maximum temperature (Tmax.) and had a non-significant and positive correlation with minimum temperature (Tmin.) and sun shine hours (SSH) $(r=0.513,0.287$ and 0.452) on $\mathrm{CoH} 160,(r=0.504$, 0.321 and 0.431$)$ on $\mathrm{CoH} 119$ and $(r=0.537,0.276$ and 0.445$)$ on CoS 767 , respectively whereas it has non-significant and negative correlation with relative humidity (morning), relative humidity (evening) andrainfall $(r=-0.172,-0.206$ and -0.147$)$ on $\mathrm{CoH} 160$, $(r=-$ $0.147,-0.172$ and -0.130$)$ on $\mathrm{CoH} 119$ and $(r=-0.187,-0.223$ and -0.160$)$ on CoS 767. Multiple regression analysis of $C$. infuscatellus population with weather parameters showed that there was 77 per cent $(\mathrm{CoH} 160), 75$ per cent $(\mathrm{CoH} 119)$ and 76 per cent (CoS767) variability in dead heart formation due to various environmental factors. The population dynamics revealed by this study have far reaching significance in pest management strategy as integrated control measures may be focused only during the period wherein population exceeds economic threshold level (ETL).
\end{abstract}

Keywords: Population dynamics, Chilo infuscatellus, Sugarcane, Weather conditions

\section{INTRODUCTION}

Sugarcane (Saccharum officinarum L.) is a large stature perennial grass that is cultivated in approximately 80 nations in tropical, semi-tropical, and sub-tropical regions of the world, primarily for its ability to store high concentrations of sucrose in the stem. Sugarcane is amongst most efficient crops in the world in converting energy from sunlight to chemical energy that is usable as a fuel source. Sugarcane is a raw material for the production of white sugar, khandsari and jaggery (gur). It is also used for chewing and extraction of juice for beverage purpose. In India, sugarcane cultivation and sugar industry plays a vital role towards socio-economic development by mobilizing rural resources and generating higher income and employment opportunities. About 45 million

\section{Article Info}

DOI: 10.31018/jans.v10i4.1922 Received: October 12, 2018 Revised: November 20, 2018 Accepted: November 29, 2018

\section{How to Cite}

Kumar, K. et al. (2018). Population dynamics of early shoot borer, Chilo infuscatellus Snellen on sugarcane as influenced by weather conditions. Journal of Applied and Natural Science, 10(4): 1297-1302 sugarcane farmers and their dependents including agricultural labourer are involved in Indian sugar industry (Dhanraj and Dharne, 2013). Sugar industry is second largest agro-based industry which comprises of more than 500 sugar mills, next to textiles (Takale, 2013). Besides sugar production, sugarcane produces numerous valuable by-products like, alcohol used by pharmaceutical industry, ethanol used as a fuel, production of electricity power and press mud used as a rich source of organic matter for crop production. Major sugarcane growing countries are Brazil, India, China, Thailand, Pakistan, Mexico, Australia, Philippines, Argentina and Colombia. It is an important commercial cash crop grown in India, supporting second large agro-based industry. In India, sugarcane occupies an area of 4.51 million ha with annual production of 305.25 million tones and productivi- 
ty of 67.57 tones per ha, whereas in Haryana it occupies an area of 0.11 million ha with the production of 8.53 million tones and productivity of 74.21 tones per ha (Anonymous, 2016).

Sugarcane is the long duration crop with luxuriant vegetative growth. There are a number of causes responsible for low yield of sugarcane but losses caused by insect-pests are of prime importance. One of the major constraints in maximizing production is losses due to insect-pests, as sugarcane plant is vulnerable to attack by various insect-pests right from germination till to the harvest of the crop. Sugarcane is vulnerable to several insect-pests at all the stages of crop growth, both in sub-tropical and tropical regions of the country and this problem is more serious in the sub-tropical region than in tropical regions of the country. Sugarcane by virtue of its growth provides homogenous agroecosystem and thereby serving as abundant source of shelter and food to a host of organisms over considerable period of year (Chaudhary, 2008). Sugarcane is damaged by a number of insect-pests during its crop growth. In India, 211 species have been recorded, out of which 18 species have attained major pest status (David and Nandgopal, 1986). Amongst various insect-pests, termites, borers, pyrilla, whiteflies and bugs etc. attack the crop and causes heavy losses in yield and quality. Among these pests, borers are the key factors in causing crop losses in plant stand and number of millable canes which results in huge loss of sugar (Sharma et al., 2011). Borers are the major pests attacking sugarcane throughout growth period, starting from germination to harvesting of the crop in the field. Amongst tissue borers, early shoot borer, Chilo infuscatellus Snellen; top borer, Scirpophaga nivella; root borer, Emmalocera depressella and stalk borer, C. auricilius are major pests in sub-tropical region. Early shoot borer, $C$. infuscatellus attacks in early phase of plant growth by entering laterally through holes in the shoot and damage complete cane by boring producing 'dead hearts'. Its caterpillars destroy about 20 per cent of the young shoots during April to June (Dhaliwal and Atwal, 2004). C. infuscatellus destroys approximately 60 per cent of the mother shoots, 35 to 43 per cent of tillers and 15.8 to 41.8 per cent reduction in yield which ultimately reduces cane yield (Jhansi, 2009). In India, this species is widely distributed particularly in sugarcane growing parts of the country (Karnataka, Bihar, Haryana, Punjab, Uttar Pradesh, Gujarat and Tamil Nadu).

C. infuscatellus has become very serious pest in recent years in sub-tropics and causes economic damage to the production of sugarcane. Thus, it is very necessary to find out management strategies for this pest for higher production of sugarcane. Under field conditions, there is a specific time period at which $C$. infuscatellus population reaches at its peak. Meteorological factors play a vital role for development and population build-up of insect species. A thorough knowledge of population dynamics of an insect-pest in relation to biotic and abiotic factors is essential for developing efficient pest management strategies. Keeping in view, to predict peak period of its incidence and to develop an effective pest management strategy, it was felt necessary to study population dynamics of C. infuscatellus.

\section{MATERIALS AND METHODS}

To study the population dynamics of $C$. infuscatellus during 2016-17 crop season, three sugarcane cultivars of different maturity groups viz., $\mathrm{CoH} 160$ (early), CoH 119 (mid), CoS 767 (late) were planted in a plot size of $5.25 \times 10 \mathrm{~m}$ (6 rows of $10 \mathrm{~m}$ row length) with a spacing of $75 \mathrm{~cm}$ at the research farm of CCS Haryana Agricultural University, Regional Research Station, Karnal in a randomized block design in three replications. The crop was kept free from insecticides starting from planting to the harvest and all other recommended agronomic practices were followed to raise the crop.

Incidence of $C$. infuscatellus was recorded at weekly interval starting from germination of crop up to $4^{\text {th }}$ week of July. The dead heart counts were made from 6 rows of $10 \mathrm{~m}$. row length in each cultivar and replicated thrice. All the plants showing symptoms of dead heart were also uprooted from field and brought to laboratory and dissected on the same day by splitting open for recording parasitisation, if any. Per cent borer infestation was calculated on dead heart basis as per following formula:

Dead heart formation $(\%)=$ Total number of dead hearts / Total number of shoots $\times 100 \quad$.......(Eq.1) Data was correlated with abiotic factors i.e. temperature $\left({ }^{\circ} \mathrm{C}\right)$, relative humidity $(\%)$, sunshine hours (hours) and rainfall ( $\mathrm{mm}$ ).

Meteorological data: Data on weather parameter such as temperature, relative humidity, sunshine hours and rainfall was obtained from meteorological observatory of Central Soil Salinity Research Institute (CSSRI), Karnal, Haryana. The results on population dynamics of $C$. infuscatellus were discussed in relation to these parameters.

Statistical analysis: Correlations of population dynamics of $C$. infuscatellus during different observation periods with different meteorological parameters were worked out. Regression analysis between $C$. infuscatellus populations with abiotic factors (meteorological) was worked out using SPSS 16.0 version.

\section{RESULTS AND DISCUSSION}

Population dynamics: The results of the present investigations on population dynamics of $C$. infuscatellus on sugarcane genotypes, $\mathrm{CoH} 160$ (early), CoH 119 (mid) and CoS 767 (late) during 
Kumar, K. et al. / J. Appl. \& Nat. Sci. 10 (4): 1297-1302 (2018)

Table 1. Population dynamics of C. infuscatellus on sugarcane genotype $\mathrm{CoH} 160$ (early).

\begin{tabular}{|c|c|c|c|c|c|c|c|c|c|}
\hline S. N. & Date/ Month & SMW & $\begin{array}{l}\text { DH } \\
(\%)\end{array}$ & $\begin{array}{l}\mathrm{T} \\
(\max )^{\circ} \mathrm{C}\end{array}$ & $\begin{array}{l}\mathrm{T} \\
(\min ){ }^{\circ} \mathrm{C} \\
\end{array}$ & $\begin{array}{l}\text { RH (M) } \\
(\%)\end{array}$ & $\begin{array}{l}\text { RH (E) } \\
(\%)\end{array}$ & $\begin{array}{l}\begin{array}{l}\text { Rainfall } \\
(\mathbf{m m})\end{array} \\
\end{array}$ & SSH (hr) \\
\hline 1 & 02 April - 08 April & 14 & 0 & 36.3 & 19.2 & 68.4 & 23.7 & 0 & 7.2 \\
\hline 2 & 09 April - 15 April & 15 & 0.23 & 35.8 & 16.8 & 55.9 & 15.4 & 0 & 8.7 \\
\hline 3 & 16 April - 22 April & 16 & 0.46 & 39.4 & 20.8 & 53.9 & 16.4 & 0 & 7.8 \\
\hline 4 & 23 April - 29 April & 17 & 0.78 & 38.4 & 17.4 & 39.7 & 8 & 0 & 9.2 \\
\hline 5 & 30 April - 06 May & 18 & 0.92 & 38.8 & 22.3 & 48.1 & 27.3 & 0 & 6.2 \\
\hline 6 & 07 May - 13 May & 19 & 1.70 & 37.1 & 23.7 & 66.9 & 35 & 24.2 & 8.8 \\
\hline 7 & 14 May - 20 May & 20 & 0.94 & 41.6 & 24.9 & 52.3 & 27.4 & 0 & 11.1 \\
\hline 8 & 21 May - 27 May & 21 & 2.79 & 37.8 & 24.2 & 64.1 & 34.4 & 10.4 & 8.5 \\
\hline 9 & 28 May - 03 June & 22 & 2.12 & 38.6 & 25.4 & 63.1 & 33.5 & 0 & 9.6 \\
\hline 10 & 04 June - 10 June & 23 & 3.70 & 39.9 & 26.0 & 70.3 & 32.3 & 0 & 9.4 \\
\hline 11 & 11 June - 17 June & 24 & 3.81 & 38.2 & 26.0 & 66.3 & 38.3 & 14.5 & 8.4 \\
\hline 12 & 18 June - 24 June & 25 & 1.85 & 36.3 & 26.8 & 73.9 & 56 & 5.9 & 7.3 \\
\hline 13 & 25 June - 01 July & 26 & 0.90 & 37.1 & 27.4 & 82.1 & 56.3 & 19.4 & 2.6 \\
\hline 14 & 02 July - 08 July & 27 & 0.29 & 33.8 & 25.7 & 89.4 & 70.6 & 85.6 & 4.9 \\
\hline 15 & 09 July - 15 July & 28 & 0.27 & 34.4 & 27.7 & 83.9 & 68.9 & 12 & 5.7 \\
\hline 16 & 16 July - 22 July & 29 & 0.24 & 32 & 26.3 & 89.9 & 73.4 & 10.6 & 6.8 \\
\hline 17 & 23 July - 29 July & 30 & 0 & 34 & 26.4 & 87.9 & 71.6 & 14.2 & 2.6 \\
\hline
\end{tabular}

SMW - Standard meteorological week, DH - Dead heart, T(max) - Temperature (maximum), T(min) - Temperature (minimum), RH (M) - Relative humidity (morning), RH (E) - Relative humidity (evening) and SSH - Sun shine hours

Table 2. Population dynamics of C. infuscatellus on sugarcane genotype $\mathrm{CoH} 119$ (mid).

\begin{tabular}{|c|c|c|c|c|c|c|c|c|c|}
\hline S. N. & Date/ Month & SMW & $\begin{array}{l}\text { DH } \\
(\%)\end{array}$ & $\begin{array}{l}\mathrm{T} \\
(\max )^{\circ} \mathrm{C}\end{array}$ & $\begin{array}{l}\mathrm{T} \\
(\min )^{\circ} \mathrm{C}\end{array}$ & $\begin{array}{l}\text { RH (M) } \\
(\%)\end{array}$ & $\begin{array}{l}\text { RH (E) } \\
(\%)\end{array}$ & $\begin{array}{l}\begin{array}{l}\text { Rainfall } \\
(\mathbf{m m})\end{array} \\
\end{array}$ & SSH (hr) \\
\hline 1 & 02 April - 08 April & 14 & 0 & 36.3 & 19.2 & 68.4 & 23.7 & 0 & 7.2 \\
\hline 2 & 09 April - 15 April & 15 & 0.31 & 35.8 & 16.8 & 55.9 & 15.4 & 0 & 8.7 \\
\hline 3 & 16 April - 22 April & 16 & 0.58 & 39.4 & 20.8 & 53.9 & 16.4 & 0 & 7.8 \\
\hline 4 & 23 April - 29 April & 17 & 0.92 & 38.4 & 17.4 & 39.7 & 8 & 0 & 9.2 \\
\hline 5 & 30 April - 06 May & 18 & 1.05 & 38.8 & 22.3 & 48.1 & 27.3 & 0 & 6.2 \\
\hline 6 & 07 May - 13 May & 19 & 2.26 & 37.1 & 23.7 & 66.9 & 35 & 24.2 & 8.8 \\
\hline 7 & 14 May - 20 May & 20 & 1.51 & 41.6 & 24.9 & 52.3 & 27.4 & 0 & 11.1 \\
\hline 8 & 21 May - 27 May & 21 & 3.96 & 37.8 & 24.2 & 64.1 & 34.4 & 10.4 & 8.5 \\
\hline 9 & 28 May - 03 June & 22 & 2.43 & 38.6 & 25.4 & 63.1 & 33.5 & 0 & 9.6 \\
\hline 10 & 04 June - 10 June & 23 & 4.47 & 39.9 & 26.0 & 70.3 & 32.3 & 0 & 9.4 \\
\hline 11 & 11 June - 17 June & 24 & 4.60 & 38.2 & 26.0 & 66.3 & 38.3 & 14.5 & 8.4 \\
\hline 12 & 18 June - 24 June & 25 & 2.98 & 36.3 & 26.8 & 73.9 & 56 & 5.9 & 7.3 \\
\hline 13 & 25 June - 01 July & 26 & 1.49 & 37.1 & 27.4 & 82.1 & 56.3 & 19.4 & 2.6 \\
\hline 14 & 02 July - 08 July & 27 & 0.41 & 33.8 & 25.7 & 89.4 & 70.6 & 85.6 & 4.9 \\
\hline 15 & 09 July - 15 July & 28 & 0.36 & 34.4 & 27.7 & 83.9 & 68.9 & 12 & 5.7 \\
\hline 16 & 16 July - 22 July & 29 & 0.34 & 32 & 26.3 & 89.9 & 73.4 & 10.6 & 6.8 \\
\hline 17 & 23 July - 29 July & 30 & 0 & 34 & 26.4 & 87.9 & 71.6 & 14.2 & 2.6 \\
\hline
\end{tabular}

SMW - Standard meteorological week, DH - Dead heart, T(max) - Temperature (maximum), T(min) - Temperature (minimum), RH (M) - Relative humidity (morning), RH (E) - Relative humidity (evening) and SSH - Sun shine hours

2016 are presented in Tables 1, 2 and 3 and graphically in Fig.1. Results indicated that dead heart formation found from $14^{\text {th }} \mathrm{SMW}$ to $30^{\text {th }}$ SMW, 2016 (first week of April to last week of July). The average dead heart formation by early shoot borer varied from 0 to 3.81 per cent in $\mathrm{CoH}$ 160,0 to 4.6 per cent in $\mathrm{CoH} 119$ and 0 to 3.12 per cent in CoS 767 from $14^{\text {th }} \mathrm{SMW}$ to $30^{\text {th }} \mathrm{SMW}$, 2016 (first week of April to last week of July). Kumar et al. (2004) reported that C. infuscatellus infestation started from first week of February with an initial level of 0.86 per cent. They also reported that from February onwards, pest infestation gradually increased and reached to its peak level by end of May $(5.09 \%)$. They further revealed that from June onwards its infestation declined and no infestation was observed during July. Therefore, findings of these workers support the results of present investigations. Pandey and Kumar (2014) studied that the infestation of $C$. infuscatellus in sugarcane variety CoS 8436 started from $1^{\text {st }}$ week of May $\left(19^{\text {th }}\right.$ SMW $)$ and continued upto $4^{\text {th }}$ week of June $\left(26^{\text {th }} \mathrm{SMW}\right)$ also support present findings. However, Kalariya and Radadia (2013) reported the highest dead heart formation (6.29\%) during $3^{\text {rd }}$ week of April and incidence declined during first week of June and disappeared by middle of June when crop was in formative stage. The variations in $C$. infuscatellus incidence as reported by them to that of present studies may be due to meteorological factors as studies were conducted at Navsari in Gujarat state. Chaudhary et al. (2015) 
Table 3. Population dynamics of $C$. infuscatellus on sugarcane genotype $\operatorname{CoS} 767$ (late).

\begin{tabular}{llllllllll}
\hline S. N. & Date/ Month & $\mathbf{S M W}$ & $\begin{array}{l}\mathbf{D H} \\
\mathbf{( \% )}\end{array}$ & $\mathbf{T}(\mathbf{m a x})^{\mathbf{0}} \mathbf{C}$ & $\mathbf{T}(\mathbf{m i n}) \mathbf{~}^{\mathbf{0}} \mathbf{C}$ & $\begin{array}{l}\mathbf{R H}(\mathbf{M}) \\
(\mathbf{\%})\end{array}$ & $\begin{array}{l}\mathbf{R H}(\mathbf{E}) \\
(\mathbf{\%})\end{array}$ & $\begin{array}{l}\text { Rainfall } \\
(\mathbf{m m})\end{array}$ & $\begin{array}{l}\text { SSH } \\
(\mathbf{h r})\end{array}$ \\
\hline 1 & 02 April - 08 April & 14 & 0 & 36.3 & 19.2 & 68.4 & 23.7 & 0 & 7.2 \\
2 & 09 April - 15 April & 15 & 0.15 & 35.8 & 16.8 & 55.9 & 15.4 & 0 & 8.7 \\
3 & 16 April - 22 April & 16 & 0.37 & 39.4 & 20.8 & 53.9 & 16.4 & 0 & 7.8 \\
4 & 23 April - 29 April & 17 & 0.59 & 38.4 & 17.4 & 39.7 & 8 & 0 & 9.2 \\
5 & 30 April - 06 May & 18 & 0.76 & 38.8 & 22.3 & 48.1 & 27.3 & 0 & 6.2 \\
6 & 07 May - 13 May & 19 & 1.21 & 37.1 & 23.7 & 66.9 & 35 & 24.2 & 8.8 \\
7 & 14 May - 20 May & 20 & 0.79 & 41.6 & 24.9 & 52.3 & 27.4 & 0 & 11.1 \\
8 & 21 May - 27 May & 21 & 1.94 & 37.8 & 24.2 & 64.1 & 34.4 & 10.4 & 8.5 \\
9 & 28 May - 03 June & 22 & 1.53 & 38.6 & 25.4 & 63.1 & 33.5 & 0 & 9.6 \\
10 & 04 June - 10 June & 23 & 2.92 & 39.9 & 26.0 & 70.3 & 32.3 & 0 & 9.4 \\
11 & 11 June - 17 June & 24 & 3.12 & 38.2 & 26.0 & 66.3 & 38.3 & 14.5 & 8.4 \\
12 & 18 June - 24 June & 25 & 1.22 & 36.3 & 26.8 & 73.9 & 56 & 5.9 & 7.3 \\
13 & 25 June - 01 July & 26 & 0.72 & 37.1 & 27.4 & 82.1 & 56.3 & 19.4 & 2.6 \\
14 & 02 July - 08 July & 27 & 0.23 & 33.8 & 25.7 & 89.4 & 70.6 & 85.6 & 4.9 \\
15 & 09 July - 15 July & 28 & 0.20 & 34.4 & 27.7 & 83.9 & 68.9 & 12 & 5.7 \\
16 & 16 July - 2 July & 29 & 0.18 & 32 & 26.3 & 89.9 & 73.4 & 10.6 & 6.8 \\
17 & 23 July - 29 July & 30 & 0 & 34 & 26.4 & 87.9 & 71.6 & 14.2 & 2.6 \\
\hline
\end{tabular}

SMW - Standard meteorological week, DH - Dead heart, T(max) - Temperature (maximum), T(min) - Temperature (minimum), RH (M) - Relative humidity (morning), RH (E) - Relative humidity (evening) and SSH - Sun shine hour

Table 4. Correlation of $C$. infuscatellus population with environmental factors on sugarcane genotypes (CoH 160, CoH 119 and $\operatorname{CoS} 767)$.

\begin{tabular}{lllllll}
\hline $\begin{array}{l}\text { Sugarcane } \\
\text { genotypes }\end{array}$ & $\begin{array}{l}\text { Temp. } \\
\text { (Max.) }\end{array}$ & $\begin{array}{l}\text { Temp. } \\
\text { (Min.) }\end{array}$ & $\begin{array}{l}\text { Relative } \\
\text { humidity (\%) M }\end{array}$ & $\begin{array}{l}\text { Relative } \\
\text { humidity (\%) E }\end{array}$ & $\begin{array}{l}\text { Rainfall } \\
\text { (mm) }\end{array}$ & $\begin{array}{l}\text { Sun } \\
\text { shine hours }\end{array}$ \\
\hline CoH160 & $0.513^{*}$ & $0.287^{\mathrm{NS}}$ & $-0.172^{\mathrm{NS}}$ & $-0.206^{\mathrm{NS}}$ & $-0.147^{\mathrm{NS}}$ & $0.452^{\mathrm{NS}}$ \\
CoH119 & $0.504^{*}$ & $0.321^{\mathrm{NS}}$ & $-0.147^{\mathrm{NS}}$ & $-0.172^{\mathrm{NS}}$ & $-0.130^{\mathrm{NS}}$ & $0.431^{\mathrm{NS}}$ \\
CoS767 & $0.537^{*}$ & $0.276^{\mathrm{NS}}$ & $-0.187^{\mathrm{NS}}$ & $-0.223^{\mathrm{NS}}$ & $-0.160^{\mathrm{NS}}$ & $0.445^{\mathrm{NS}}$ \\
\hline
\end{tabular}

*Significant $(\mathrm{P}=0.05 \%)$

Table 5. Multiple regression analysis between $C$. infuscatellus population and environmental factors on sugarcane cultivars $(\mathrm{CoH}$ 160, CoH 119 and CoS 767).

\begin{tabular}{lll}
\hline Sugarcane genotypes & Regression equations & $\mathbf{R}^{2}$ \\
\hline CoH160 & $\mathrm{Y}=13.799-0.775 \mathrm{X} 1+1.043 \mathrm{X} 2-0.005 \mathrm{X} 3-0.217 \mathrm{X} 4+0.017 \mathrm{X} 5+0.006 \mathrm{X} 6$ & 0.77 \\
$\mathrm{CoH} 119$ & $\mathrm{Y}=14.829-0.887 \mathrm{X} 1+1.254 \mathrm{X} 2-0.007 \mathrm{X} 3-0.253 \mathrm{X} 4+0.021 \mathrm{X} 5+0.020 \mathrm{X} 6$ & 0.75 \\
CoS767 & $\mathrm{Y}=9.336-0.556 \mathrm{X} 1+0.785 \mathrm{X} 2-0.001 \mathrm{X} 3-0.164 \mathrm{X} 4+0.012 \mathrm{X} 5-0.005 \mathrm{X} 6$ & 0.76 \\
\hline
\end{tabular}

Where, X1 = Temperature (maximum), X2 = Temperature (minimum), X3 = Relative humidity (morning), X4 = Relative humidity (evening), X5 = Rainfall $(\mathrm{mm}), \mathrm{X} 6=$ Sun shine hours

reported that $C$. infuscatellus infestation starts from $2^{\text {nd }}$ week of February and remained upto $2^{\text {nd }}$ week of July while peak incidence (1.3 to 2.10 per cent dead heart formation/week) was observed from last week of March to second last week of May support the present findings.

The highest incidence (dead heart formation) of $C$. infuscatellus was recorded 3.81 per cent in $\mathrm{CoH}$ 160, 4.60 per cent in $\mathrm{CoH} 119$ and 3.12 per cent in CoS 767 during $24^{\text {th }}$ SMW (11 June -17 June) at $38.2^{\circ} \mathrm{C}$ maximum temperature, $26.0^{\circ} \mathrm{C}$ minimum temperature, morning relative humidity 66.3 per cent, evening relative humidity 38.3 per cent and 8.4 sun shine hours. The experimental trials conducted by Pandey and Kumar (2014) who revealed that the highest incidence of $C$. infuscatellus in sugarcane was observed during $21^{\text {st }}$ SMW (8.8 per cent) at $43.1^{\circ} \mathrm{C}$ maximum temperature, $28.4^{\circ} \mathrm{C}$ minimum temperature, 57.0 per cent maximum relative humidity, 21.0 per cent mini- mum relative humidity and 9.1 sun shine hours support the present findings. Choudhary et al. (2015) revealed that for built up of peak activity of C. infuscatellus in sugarcane, 39 to $40^{\circ} \mathrm{C}$ maximum and 13 to $17^{\circ} \mathrm{C}$ minimum temperature, 69 to 72 per cent morning and 20 to 24 per cent evening relative humidity seemed to be favourable support the present investigations.

Impact of weather on pest activity: Different environmental variables seemed to affect $C$. infuscatellus population in different ways. C. infuscatellus infestation had a significant positive correlation with maximum temperature (Tmax.) and had a non-significant and positive correlation with minimum temperature (Tmin.) and sun shine hours (SSH) $(r=0.513,0.287$ and 0.452$)$ on $\mathrm{CoH} \mathrm{160,}$ $(r=0.504,0.321$ and 0.431$)$ on $\mathrm{CoH} 119$ and(r= $0.537,0.276$ and 0.445 ) on CoS 767 , respectively. The results also revealed that there was nonsignificant and negative correlation with relative 
Kumar, K. et al. / J. Appl. \& Nat. Sci. 10 (4): 1297-1302 (2018)

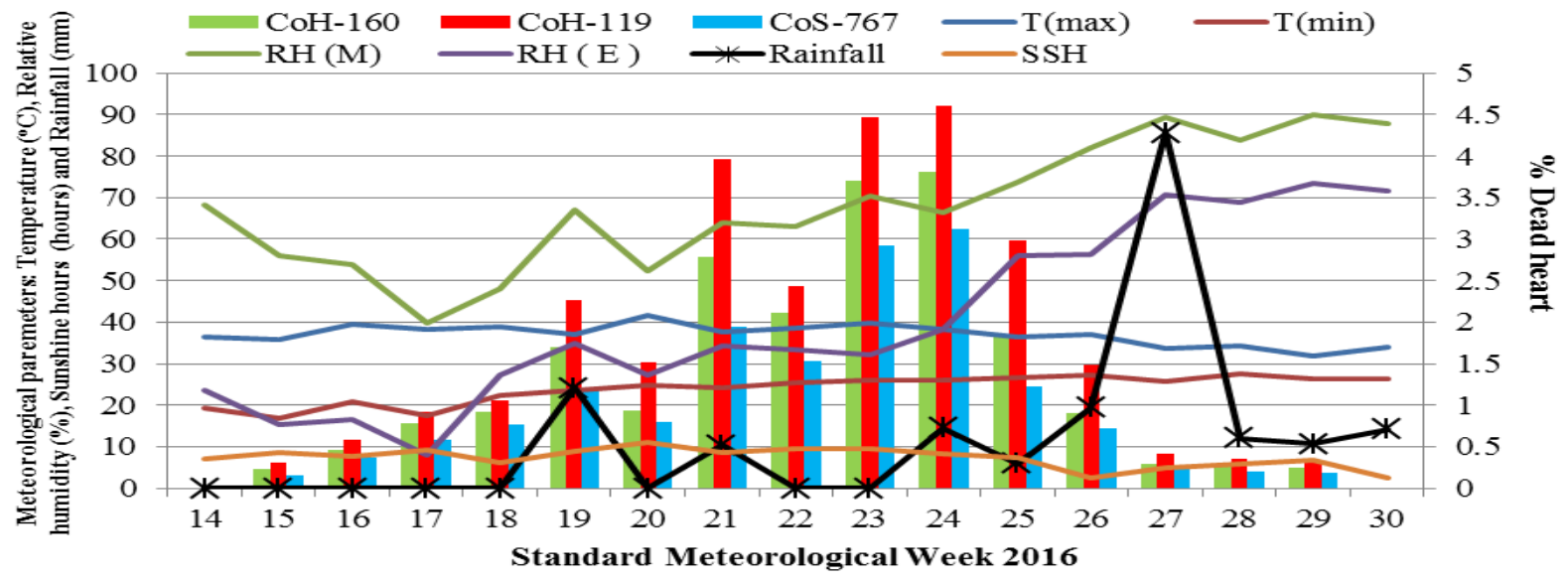

Fig. 1. Population dynamics of C. infuscatellus on sugarcane genotypes.

humidity (morning), relative humidity (evening) andrainfall $(r=-0.172,-0.206$ and -0.147$)$ on $\mathrm{CoH}$ 160, $(r=-0.147,-0.172$ and -0.130 ) on $\mathrm{CoH} 119$ and $(r=-0.187,-0.223$ and -0.160$)$ on CoS 767 , respectively (Table 4 ). A non-significant correlation of dead heart formation in different genotypes was also reported. Kumar et al. (2004) correlated the per cent incidence of $C$. infuscatellus with weather parameters. Maximum and minimum temperatures showed positive correlation ( $r=$ 0.897 and $r=0.642$ ) whereas relative humidity and rainfall showed negative correlation $(r=-0.817$ and $r=-0.088$ ) support the present findings. The findings of Pandey and Kumar (2014) who reported that maximum temperature, sun shine hours and minimum relative humidity showed a negative correlation ( $r=-0.754,-0.003$ and -0.461$)$ with $C$. infuscatellus population in sugarcane support the present investigations.

Multiple regression analysis: The multiple regression analysis, which explained the average relationship between $C$. infuscatellus and weather parameter i.e. the trend of changes in C. infuscatellus population per unit change in weather parameters, indicated that there was also significant 77 per cent, 75 per cent and 76 per cent contribution of these factors $\left(R^{2}=0.77\right.$ in $\mathrm{CoH} 160, R^{2}=$ 0.75 in $\mathrm{CoH} 119$ and $\mathrm{R}^{2}=0.76$ in $\mathrm{CoS} 767$ ) for variability in dead heart formation (Table 5). In the present studies, regression coefficients for maximum temperature, minimum temperature, morning relative humidity, evening relative humidity, rainfall and sun shine hours were $-0.775,1.043$, $0.005,-0.217,0.017$ and 0.006 in $\mathrm{CoH} 160$; $0.887,1.254,-0.007,-0.253,0.021$ and 0.020 in $\mathrm{CoH} 119$ and $-0.556,0.785,-0.001,-0.164,0.012$ and -0.005 in CoS767, respectively(Table 5). Experiments conducted on $C$. infuscatellus population in sugarcane by Pandey and Kumar (2014) recorded the regression coefficients for maximum temperature, minimum temperature, maximum relative humidity, minimum relative humidity and sun shine hours were - 0.753, 0.677, 0.0760, -
0.118 and 0.324 respectively support the present findings.

Population dynamics of insect-pests have been shifted over the years due to indiscriminate use of agro chemicals and climate change which may alter the qualitative and quantitative traits of sugarcane. Several insect pests, that were important in the past or the minor pests, are likely to become more devastating with global warming and climate change (Sharma, 2012). Although, present investigations are partially supported by finding of previous workers. However, it is an established fact that population dynamics of any insect is greatly influenced by weather fluctuations and there by the location specific studies became more imperative to study impact of climate change on population built up of $C$. infuscatellus in sugarcane.

\section{Conclusion}

The information on population dynamics of any insect pest in a given ecological niche should be considered as starting point for evolving ecofriendly pest management package. It is an established fact that population dynamics of any insect is greatly influenced by weather fluctuations and thereby the location specific studies become more imperative. Correlation of $C$. infuscatellus with different weather variables revealed that different environmental variables affect $C$. infuscatellus population in different ways. Maximum temperature had significant and positive correlation with $C$. infuscatellus population and minimum temperature and sunshine hours also showed positive correlation with pest population, whereas it had negative correlation with relative humidity and rainfall. A non-significant correlation of dead heart formation in different genotypes was also reported. The population dynamics revealed by this study has far reaching significance in pest management strategy as integrated control measures may be focused only during the period wherein population exceeds economic threshold level (ETL). 


\section{REFERENCES}

1. Anonymous. (2016). Government of India, Ministry of Agriculture, Department of Agriculture, Cooperation and farmer welfare, National Food Security Mission (NFSM)-Commercial Crops (CC).

2. Chaudhary, A.K., Amrate, P.K. and Chatterjee, A. (2015). Population dynamics of sugarcane early shoot borer in Madhya Pradesh. JNKVV Res. J., 49 (2): 208-213.

3. Chaudhary, J.P. (2008). Control of different borers in sugarcane crop. Coop. Sug., 40(3): 29-38.

4. David, H. and Nandgopal, H. (1986). Pests of sugarcane - Distribution, symptomology of attack and identification. In: Sugarcane Entomology in India (Eds. David, H. and Easwaramoorthy, S. and Jayanthi, R.) ICAR Publication, Coimbatore, pp 1-29.

5. Dhaliwal, G.S. and Atwal, A.S. (2004). Agricultural pests of South Asia and their management ( $4^{\text {th }}$ edition). Kalyani Publishers, Ludhiana-New Delhi, India, p. 498.

6. Dhanraj, T. P. and Dharne, S. R. (2013). Review of sugar industries in Maharashtra state. Laxmi Book Publication. 3(4): 54-59.

7. Jhansi. (2009). Screening of Sugarcane varieties for resistance to shoot borer, Chilo infuscatellus Snellen.
Insect Envt., 14(4): 157-159.

8. Kalariya, G. B. and Radadia, G. G. (2013). Evaluation of sugarcane genotypes against Chilo infuscatellus Snellen (Crambidae: Lepidoptera). Indian J. Ent., 75 (3): 250-252.

9. Kumar, Sunil K., UmaMaheswari T. and Venugala Rao, N. (2004).Biology and seasonal incidence of sugarcane early shoot borer (Chilo infuscatellus SnelIen) in Southern zone of Andhra Pradesh. Indian J. Ent., 66(3): 246-250.

10.Pandey, S.K. and Kumar, R. (2014).Impact analysis of weather factors in relation to early shoot borer (Chilo infuscatellus Snellen) incidence in summer planted sugarcane after wheat harvest in subtropics. Indian J. Agric. Res.,48(3): 227-231.

11.Sharma, H. C. (2012). Climate change effects on activity and abundance of insects: Implications for Crop Protection and Food Security. In: Kang MS, Banga SS (Ed) Combating Climate Change: An Agricultural Perspective. Taylor and Francis, Boca Raton, Florida, USA.

12.Sharma, S., Sandhu, S. K. and Singh, H. S. (2011). Field evaluation of sugarcane germplasm against major pests. Indian J. Sug. Res. Dev., 6:81-86

13. Takale, D. P. (2013). Progress and problems of agrobased industries in India: A study of sugar industry. Ind. Streams Res. J., 3(1): 44-51. 